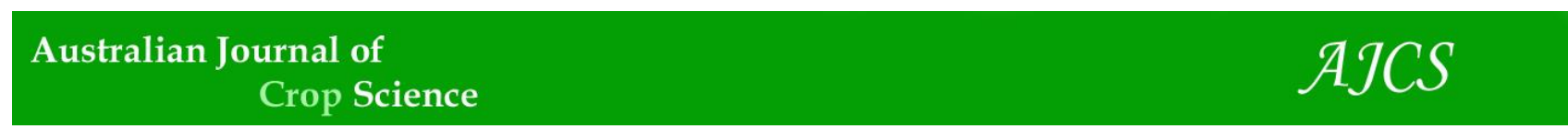

AJCS 13(02):321-327 (2019)

ISSN:1835-2707

doi: 10.21475/ajcs.19.13.02.p1733

\title{
Efficacy of biological insecticides against Helicoverpa armigera in sweet corn crop (Zea mays saccharata)
}

\author{
Mohammad Yunus ${ }^{1 *}$, Effendy ${ }^{2}$ \\ ${ }^{1}$ Department of Agriculture, Agriculture Faculty of Tadulako University, Palu, Indonesia, 94118 \\ ${ }^{2}$ Department of Agriculture Economics, Agriculture Faculty of Tadulako University, Palu, Indonesia, 94118
}

*Corresponding author: mohammad.yunus@yahoo.com

\begin{abstract}
Helicoverpa armigera Hubner ( $H$. armigera) is a significant pest to corn crops and constant problem for farmers. The objective of this research was to obtain a more effective insecticide for suppressing the population and intensity of $H$. armigera, as well as providing high economic value for sweet corn crops. This experiment used a randomized block design, consisting of 4 treatments and 6 replications. The treatments consisted of a control $(\mathrm{PO}=$ without insecticides), $\mathrm{P} 1=$ biological insecticide (Beauveria bassiana $5 \mathrm{~g}^{-1} \mathrm{I}^{-1}$ ), P2 = botanic insecticide (pandan wangi leaf extracts $5 \mathrm{ml} . .^{-1}$ ), and P3 = chemical insecticide (Deltamethrin synthetic $3 \mathrm{ml} . \mathrm{I}^{-1}$ ). The results showed that the application of various types of insecticides has a significant effect on population density of larvae, intensity of $\mathrm{H}$. armigera presence and sweet-corn crop yield. All types of insecticides applied are highly effective but the effectiveness of Beauveria bassiana 5 g..$^{-1}$ tends to be greater in comparison to others. The highest cost-benefit ratio was obtained from the application of the biological insecticide followed by the botanic insecticide and the chemical insecticide.
\end{abstract}

Keywords: Beauveria bassiana, deltamethrin, pandan wangi, economical.

Abbreviations: H_Helicoverpa; B_Beauveria; DAC_days after cropping.

\section{Introduction}

Sweet corn (Zea mays saccharata) is a crop grown for human consumption and industrially processed food ingredients worldwide. Sweet corn is different to other corns, mainly in the expression of genes that determine the carbohydrate content of endosperm and affect the corn growth (Znidarcic, 2012). In general, sweet corn is whitehaired, whereas regular corn is red-haired. The sweet corn life cycle endures between 60-70 days (Kasryno et al., 2007). Sweet corn was entered to commercial cultivation in Indonesia in the 1980s, although on a small scale. This corn is known for its sweeter taste (Sugito et al., 1991). As well, it is an important source of fiber, minerals, and certain vitamins (Lertrat and Pulam, 2007).

Among the various obstacles of production, insects are most impactful, as sweet corn is affected by more than 50 species of insects. The main loss-causing pest is Helicoverpa armigera Hubner $(H$. armigera). This insect has a variety of host crops, such as green beans, tomatoes, beans, potatoes, cotton, and corns (Zalucki et al., 1986; Topper 1987; Fitt 1989). H. armigera is generally regarded as the most serious sweet corn pest worldwide and responsible for significant losses (Archer and Bynum 1994; Wiseman and Widstrom, 1992). As a result of its many host crops, feeding behavior, and long-range mobility, $H$. armigera is considered a formidable threat to agriculture (Guerrero et al., 2014).
H. armigera attack is first noticeable when it affects the formation of flower buds, flowers, and, young fruit. Larvae enter the young fruit, eating the corn seeds inside.

Occasionally, they move into young crop stems and buds of crop leaves, especially when the larvae population is high (Sudarmo, 1988). An H. armigera attack causes the number of corn seeds to decrease. Most significantly, if the larvae feed on the tuna hair, they interfere with the pollination process and formation of corn beans.

In an effort to control $H$. armigera, farmers in Sigi Regency Indonesia rely on the use of synthetic chemical insecticides. The application of insecticides is unscheduled and uses nonrecommended doses. This activity raises concerns regarding chemical residues on sweet corn, soil, and water, as well as other potential human and environmental hazards (Pimentel 2005; Konradsen 2007; Sam et al., 2008; Adeogun and Agbongiarhuoyi, 2009; Hou and Wu, 2010; Adejumo et al., 2014).

Farmers constantly take risks regarding the harmful effects of chemical materials. WHO and UNEP reported that pesticide use is responsible for 3 million acute poisonings and causes about 20,000 deaths annually among agricultural workers. Exposure to pesticides has long-term effects on thyroid function, causing low sperm counts in men, congenital disabilities, testicular cancer, reproductive and immune disorders, endocrine disorders, dermatitis, 
behavioral changes, cancer, immunotoxicity, and neurobehavioral and developmental disorders (Mesnage et al., 2010; Tanner et al 2011; Cocco et al. 2013; Gill and Garg 2014). Furthermore, Ntow et al. (2006) and Gill and Garg (2014) reported other short-term effects, such as a headache, body aches, skin or eye irritation, respiratory problems, weakness, dizziness, visual impairment, and nausea.

To suppress $H$. armigera and reduce the problem of residues, research focuses on control alternatives, such as botanic and biologic insecticides. One botanic insecticide in this study is derived from pandan wangi leaf extract, Pandanus amaryllifolius ( $P$. amaryllifolius). According to Kardinan (2002), pandan wangi leaf extract has an effective toxicity to kill imago insect Sitophilus oryzae (S. oryzae). The pandan wangi leaf contains alkaloids, saponins, flavonoids, tannins, polyphenols, and dyes. Saponin is a sugar compound that binds to hydrophobic aglucone, in the form of steroids or triterpenes. It can bind free sterols, the precursor to the hormone ecdyson, during digestion. In turn, decreasing the number of free sterols interferes with the insect molting process.

The superiority of botanic insecticides is noted by Grainge and Achmed (1988). They state that insects do not readily become resistant to botanic insecticides containing certain active ingredients; as well, insects simultaneously form a system of resistance to several different compounds. The pandan wangi leaf extract was tested on Sitophilus oryzae at the concentration of $5 \mathrm{ml}$ with $20 \%$ active ingredient. Using this extract the insect mortality reached $94 \%$ (Yunus et al., 2016).

The fungus Beauveria bassiana (B. bassiana) is a biological agent used in controlling populations of insect pests. Some orders of insects that host $B$. bassiana are Lepidoptera, Coleoptera, and Homoptera (Ahmad et al., 2008). B. bassiana produces toxins to control pests in a variety of crop commodities (Wraight et al. 2000). As well, it is naturally present in the soil as a saprophyte fungus and can live on insect tissue. Therefore, it is highly effective in suppressing the development of Lepidoptera larvae (Herlinda et al., 2006). This study aims to discern the most effective type of insecticide in controlling $H$. armigera and provide a high economic value for sweet corn crops.

\section{Results and Discussion}

\section{Population density of H. armigera}

ANOVA analyses show a significant effect of insecticide treatment type $(\alpha=5 \%)$ on the population density of $H$. armigera larvae, attack intensity, and sweet corn cob production. Tukey test results $(\alpha=5 \%)$ show that the lowest population density of $H$. armigera larvae is found from the treatment of $B$. bassiana $5 \mathrm{~g} \mathrm{I}^{-1}$. This yields a 0.35 tail per crop, which is not significantly different from the treatment of pandan wangi leaf extract $5 \mathrm{ml} \mathrm{I}^{-1}$ and Deltamethrin $3 \mathrm{ml} \mathrm{I}^{-1}$ (Table 1).

The results show that the application of insecticide has a significant effect on the population density of $H$. armigera larvae. The declining population density of $H$. armigera larvae is a result of the effective toxicity of each insecticide type. The population density of $H$. armigera larvae tends to be lowest ( 0.35 tail per crop) with $B$. bassiana application of $5 \mathrm{~g} \mathrm{I}^{-1}$, compared to other treatments. This is a result of the
B. bassiana attaching and growing on the young corn cob. When the larvae enter the cob, $B$. bassiana infects the insects' skin and digestive system, causing the larvae to die. When the fungus $B$. bassiana is in contact with the outer skin of the insect, spores form a sprout tube to penetrate the skin and body fat and reach the hemocoel (Jauharlina, 1998). Next conidia grew in the infected insect epicycles around parts of the body, such as appressoria. Penetration lasts for 12-24 hours, with the help of enzymes secreted by hyphae, such as chitinases, lipases, and proteases. In the epidermis, the mycelia grow radically from the center of the infection and reach the hemocoel within 1-2 days. Furthermore, the mycelia grow throughout the body tissues, penetrate the body surface, and form conidia (Cheung and Grula 1982; Suntoro, 1991)

B. bassiana produces toxins in the form of beauvericin compounds, consisting of four bassianolide molecules, cyclodepsipeptides I-N methylleaucyl-dhidroxysovalerik. These compounds poison mosquito larvae, saltwater prawns and bacteria, causing disruption during the exchange of substances between cells at Luecophase maderae (Tanada and Harry, 1993). B. bassiana also produces beauverolite, bassianolite, isorolite, pigment and oxalic acid. It causes increased blood $\mathrm{pH}$, blood clots and cessation of blood circulation in insects.

Furthermore, the fungus also causes mechanical damage to the hemocoel in tissues and organs, such as the respiratory tract, muscles, nervous system, and respiratory system. The consequences of this whole process lead to insect death (Cheung and Grula 1982). Once the insect dies, the entire body is covered with hyphae and hardens. If colored white, the spore flour growth enveloping the cadaver is suspected to be an infection of B. bassiana (Riyatno and Santoso, 1991; Patulak, 1995). The use of $B$. bassiana does not pollute the environment and is not harmful to the health of farmers and consumers.

An alternative control is possible by using pandan wangi leaf extracts of $5 \mathrm{ml} \mathrm{I}^{-1}$. Its effectiveness in suppressing population density of $H$. armigera larvae, at 45 tails per 100 crops, was not significantly different from B. bassiana (Table 1). Flavonoid compounds have insecticidal properties that cause nerve poisoning in some vital organs, causing insect death. The products of pandan wangi leaf extraction, using ethyl acetate, are terpenoid compounds and steroids that can kill S. oryzae insects (Elimam et al. 2009; Sukandar et al., 2016).

\section{Attack intensity}

Tukey test results ( $\alpha=5 \%$ ) show that the lowest intensity of $H$. armigera is resultant of the $B$. bassiana $5 \mathrm{~g}^{-1}$ treatment, which is $22.38 \%$ per plot. This is not significantly different from the pandan wangi leaf extract $5 \mathrm{ml} \mathrm{I}^{-1}$ and Deltamethrin $3 \mathrm{ml}^{-1}$ treatments (Table 2).

The results show that the intensity of $H$. armigera at age 70 DAC ranges from $22.38-40.89 \%$ (Table 2). Application of $B$. bassiana causes the lowest intensity of $\mathrm{H}$. armigera larvae attack of $22.38 \%$. The intensity of $H$. armigera on sweet corn cobs is closely related to the population density of $H$. armigera larvae. The regression analysis gives a slope of $\mathrm{Y}=$ $52.49 \mathrm{X}+7.46, \mathrm{R}^{2}=0.949$ (Figure 1). Therefore, a higher larvae population density is associated with a higher attack intensity. 
Table 1. Average population density of $H$. armigera larvae on sweet corn cobs.

\begin{tabular}{lc}
\hline Treatments & Density average (tail per crop)* \\
\hline Control (without insecticide) & $0.68^{\text {a }}$ \\
Fungus B. bassiana of $5 \mathrm{~g} \mathrm{I}^{-1}$ & $0.35^{\mathrm{b}}$ \\
Liquid extracts of pandan wangi leaf of $5 \mathrm{mll}^{-1}$ & $0.45^{\mathrm{b}}$ \\
Deltamethrin chemical insecticide of $3 \mathrm{mll}^{-1}$ & $0.37^{\mathrm{b}}$ \\
\hline
\end{tabular}

${ }^{*}$ The different letters were significant at $\alpha=5 \%(p<0.05)$.

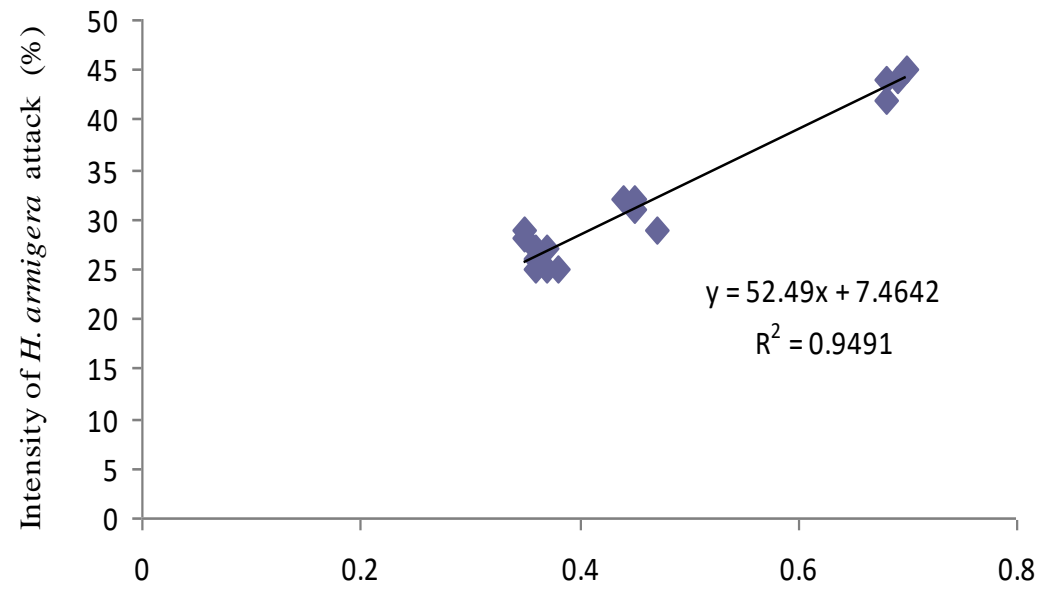

Population density of $H$. armigera per crop

Fig 1. Relation between larvae population density and intensity of $H$. armigera attack.

Table 2. Average intensity of $H$. armigera attacks (\%) on sweet corn cobs.

\begin{tabular}{ll}
\hline Treatments & Average of attack intensity (\%)* \\
\hline Control (without insecticide) & $40.89^{\mathrm{a}}$ \\
Fungus B. bassiana of $5 \mathrm{~g} \mathrm{I}^{-1}$ & $22.38^{\mathrm{b}}$ \\
Liquid extracts of pandan wangi leaf of $5 \mathrm{mlI}^{-1}$ & $25.49^{\mathrm{b}}$ \\
Deltamethrin chemical insecticide of $3 \mathrm{mII}^{-1}$ & $25.88^{\mathrm{b}}$ \\
\hline
\end{tabular}

* The different letters were significant at $\alpha=5 \%(p<0.05)$.



Intensity of $H$. armigera attack (\%)

Fig 2. Relation between attack intensity with production of sweet corn cobs. 
Table 3. Production of sweet corn cobs.

\begin{tabular}{ll}
\hline Treatments & Average of sweet corn cobs production $\left(\text { ton ha }{ }^{-1}\right)^{*}$ \\
\hline Control (without insecticide) & $11.64^{\mathrm{a}}$ \\
Fungus B. bassiana of $5 \mathrm{~g} \mathrm{I}^{-1}$ & $17.1^{\mathrm{b}}$ \\
Liquid extracts of pandan wangi leaf of $5 \mathrm{ml} \mathrm{I}^{-1}$ & $15.67^{\mathrm{b}}$ \\
Deltamethrin chemical insecticide of $3 \mathrm{ml} \mathrm{I}^{-1}$ & $15.84^{\mathrm{b}}$ \\
\hline * The different letters were significant at $\alpha=5 \%(\mathrm{p}<0.05)$. &
\end{tabular}

Table 4. The analysis results of cost-benefit ratio of insecticide application benefits in sweet corn.

\begin{tabular}{|c|c|c|c|c|c|}
\hline Treatments & Cost ha ${ }^{-1}$ (IDR) & Yield (ton ha ${ }^{-1}$ ) & $\begin{array}{l}\text { Increase in yield over } \\
\text { control (ton) }\end{array}$ & Benefit (IDR) & Cost: Benefit \\
\hline $\begin{array}{l}\text { Biological } \\
\text { insecticide of } B \text {. } \\
\text { bassiana }\end{array}$ & $1,800,000$ & 17.10 & 5.46 & $10,920,000$ & $1: 6.07$ \\
\hline $\begin{array}{l}\text { chemical insecticide } \\
\text { of Deltamethrin } \\
\text { synthetic }\end{array}$ & $2,340,000$ & 15.84 & 4.20 & $8,400,000$ & $1: 3.59$ \\
\hline $\begin{array}{l}\text { botanic insecticide } \\
\text { of pandan wangi } \\
\text { leaf extracts }\end{array}$ & $1,530,000$ & 15.67 & 4.03 & $8,060,000$ & $1: 5.27$ \\
\hline $\begin{array}{l}\text { Without insecticide } \\
\text { (control) }\end{array}$ & - & 11.64 & & & \\
\hline
\end{tabular}

\section{Sweet corn production}

The Tukey test $(\alpha=5 \%$ ) shows the highest production of sweet corn cobs is associated with B. bassiana $5 \mathrm{~g} \mathrm{~L}^{-1}$, at 17.1 $\mathrm{t} \mathrm{ha} \mathrm{a}^{-1}$. This is not significantly different from pandan wangi leaf extract $5 \mathrm{mll}^{-1}$ and Deltamethrin $3 \mathrm{ml} \mathrm{I}^{-1}$ (Table 3).

Statistical analysis shows the application of various types of insecticides has a significant effect on the production of sweet corn cob per hectare. Production is closely related to a higher intensity of $H$. armigera. This relation is shown in the regression equation $Y=-0.264 X+23.50, R^{2}=0.857$ (Figure 2). Therefore, higher intensity of $H$. armigera attack is associated with a lower production of sweet corn cobs at harvest time.

\section{Cost-benefit ratio analysis}

The results of cost-benefit ratio of insecticide to sweet corn are shown in Table 4.

The economic analysis of various applications of insecticides shows the biologic insecticide of solid formulations $B$. bassiana $5 \mathrm{~g} \mathrm{I}^{-1}$ gives the greatest cost-benefit ratio and is more economically profitable, as compared to $H$. armigera. This treatment results in a sweet corn yield greater than that of the control treatment and shows a maximum cost-benefit ratio of 1:6.07. Therefore, the application of biologic insecticide of $B$. bassiana provides higher economic value in controlling $H$. armigera in sweet corn cultivation in Sigi Regency Indonesia.

\section{Materials and Methods}

\section{Field sites and Treatments}

This study is conducted in Sidera Village, Sigi Biromaru Subdistrict, Sigi Regency, Central Sulawesi Province Indonesia, at the geographical location $119^{\circ} 56^{\prime}$ East longitude, $01^{\circ} 01^{\prime}$ South latitude, and at an altitude of $176 \mathrm{~m}$ above sea level. It takes place from September to December 2015. The research is conducted using Randomized Block Design, consisting of 4 treatments and 6 replications. The treatments are as follows: $P_{0}=$ without insecticides (control), $\mathrm{P}_{1}=$ biological insecticide ( $B$. bassiana $5 \mathrm{~g}^{-1}$ water), $\mathrm{P}_{2}=$ botanic insecticide (pandan wangi leaf extracts $5 \mathrm{ml}^{-1}$ ), and $\mathrm{P}_{3}=$ chemical insecticide (Deltamethrin synthetic $3 \mathrm{ml} \mathrm{l}^{-1}$ ). The biological, botanic and chemical insecticides were dissolved in water. In general, farmers of Sigi Regency control pests by spraying insecticides containing the active ingredient Deltamethrin (Decis 2.5 EC). Deltamethrin affects a large variety of pests, from orders such as Lepidoptera, Homoptera, Coleoptera, Orthoptera, Diptera, and Thysanoptera. The recommended dose is placed in $1.5-3 \mathrm{ml}$ $\mathrm{I}^{-1}$ of water in EC formulation (Bayer, 2015).

\section{Treatments}

\section{Source B. Bassiana}

Milled corn media preparation. Milled Corn, as raw material for making media, was washed, drained, and then steamed until half-cooked. After steaming, it is lifted, cooled, and packed in $100 \mathrm{~g}$ per plastic bag. The packaged milled corn was further sterilized using an autoclave at $121^{\circ} \mathrm{C}$ and $15 \mathrm{Psi}$, for 60 minutes. After sterilisation, the milled corn medium was removed from the autoclave and cooled (Kusnadi and Sanjaya, 2003).

Pure isolate inoculation in corn medium. The inoculum source was obtained from the B. bassiana starter collection of the Crop Pest Disease Laboratory of Agriculture Faculty UNTAD. Entkas was first sprayed with alcohol, and left for 10-20 minutes. Inoculation of pure B. Bassiana, isolated in a sterile corn medium, was carried out in the aseptic 
receptacle. Plastic was inserted where the corn medium was folded, inflated and tied at the edges. After re-packaging, it was shaken and labelled with the date of inoculation. Inoculated milled corn medium was used as a starter and incubated at room temperature for 10-12 days in the dark. The starter was then ready to be used for propagation at the farm level (Kusnadi and Sanjaya, 2003).

\section{Preparation of Pandan Wangi leaf extracts}

Munawaroh and Handayani (2010) described the preparation of pandan wangi leaf extract with the following steps: (1) 3 pounds of pandan wangi leaves were dried under sunlight for 2 days, then cut into small pieces; (2) dried pandan wangi leaves were blended into powder, weighing 10 grams, wrapped with filter paper and inserted in soxhlet set; (3) the pandan wangi leaves in soxhlet were extracted with $100 \mathrm{ml}$ of $\mathrm{n}$-hexane solvent at $72-86^{\circ} \mathrm{C}$ heating temperature, until the solvent color returned to its original state. The extract of pandan wangi leaves then was purified with a soxhlet extractor at $81-96^{\circ} \mathrm{C}$, until the solvent no longer dripped. The extract produced from the soxhlet set was then rotated with an evaporator tool to separate the extract and solvent. The temperature used during separation is $62^{\circ} \mathrm{C}$, with a rotary speed of 5 to $8 \mathrm{rpm}$. The resulting extract is then dissolved in a concentration, according to the treatment protocol. It is further diluted with distilled water, using the following dilution formula:

$$
V_{1} \cdot M_{1}=V_{2} \cdot M_{2}
$$

Where;

V1 $=$ Volume before dilution

$\mathrm{V} 2=$ Volume after dilution

$\mathrm{M} 1=$ Concentration before dilution

$\mathrm{M} 2$ = Concentration after dilution

\section{Implementation of research}

Soil processing and preparation of cropping plot. The soil was processed using a plow and then was reared, cleaned, and flattened. The plots were $4 \times 3.5 \mathrm{~m}, 20 \mathrm{~cm}$ tall, $0.5 \mathrm{~m}$ apart, and $1 \mathrm{~m}$ between replications.

Cropping. The corn seeds were planted $3 \mathrm{~cm}$ into the soil, with two seeds in each hole. Thinning was done at 3 weeks after cropping and leaves one plant in each hole, with $70 \mathrm{x}$ $20 \mathrm{~cm}$ spacing. There is a total of 100 plants in a single crop plot.

Fertilization. Planting used 50g of manure per plot, placed down when the plot was made. Inorganic fertilizer was given twice, with Urea $360 \mathrm{~g}$, TSP $120 \mathrm{~g}$, and $\mathrm{KCL} 60 \mathrm{~g}$ per plot. The first fertilization was conducted at cropping time. A $1 / 3$ of Urea fertilizer was given, while TSP and $\mathrm{KCL}$ were given entirely. The second fertilization was applied when the crops were about 35 days after cropping (DAC), together with $2 / 3$ of Urea. Fertilizer was applied in a given array to the side of the crop.

Maintenance. Crop maintenance includes weeding and irrigation. Watering was done every morning and afternoon, at the beginning of growth, and then done three times a week, by draining water into the plot until the field reaches capacity.

\section{Applications of Insecticides}

The insecticides were made in a suspension, according to the treatment protocol, and then inserted into the hand sprayer. Spraying is done three times, targeting corncobs attached to the flower or fully formed cobs, aged around 42 DAC. The next application was done according to a sevenday interval until the time of approaching harvest.

\section{Observation variables}

Identify test insects. Insect larvae had a length of $1.44 \mathrm{~mm}$, with a yellowish-white body and a black head. The color of larvae varies between green, purple, yellowish, and dark brown. On the body, there were warts and hair and there was a wave line across the side. The fully grown larvae was $34.5 \mathrm{~mm}$. The larval stage ranged from 17-24 days. The pupa is reddish or bright brown, fat and shiny. Male imago of $H$. armigera is brightly and darkly colored, while the female is only bright brown. The male front wing has round dark spots, located at the center of the wing, and a wingspan of 30-40 mm (Kalshoven, 1981).

Population density of $\boldsymbol{H}$. armigera larvae. The observation of $H$. armigera larvae population density was conducted by observing the corn cob directly and counting the number of larvae present in each sample crop. A sample of 10 crops was observed. The observation was done 3 times, starting at 7 days after application and with a 1 week interval for sweet corn crop at age of 49 DAC, 56 DAC, and 63 DAC.

Attack Intensity. The attack intensity was calculated at the time of harvest with the following absolute formula (Antralina and Santoso, 2015):

$P=\frac{n}{N} .100 \%$

Where;

$\mathrm{P}=$ Attack Intensity (\%)

$\mathrm{n}=$ Number of attacked corn cobs (fruit)

$\mathrm{N}=$ Number of observed corn cobs (fruit)

Crop Production. Production of cob per hectare (measured by ton) is observed after the young harvest (fresh cob form), at a crop age of about 70 days. A total of 25 fresh cobs (weighed in grams) were sampled from each crop plot, weighed, and then averaged. Furthermore, the obtained data was converted to cob production per hectare, with the following formula (Subandi et al., 1998):

$\operatorname{production}($ ton $/ \mathrm{ha})=\frac{10,000\left(\mathrm{~m}^{2}\right)}{a} \times \frac{b}{1,000(\mathrm{~kg})}$

$\mathrm{a}=$ Area Size of Plot $\left(\mathrm{m}^{2}\right)$

$\mathrm{b}=$ Cob Production / Plot $(\mathrm{kg})$

\section{Data analysis}

Observation data is tested using Analysis of Variance (ANOVA) or Fisher test (F). If there is the effect of treatment, then the Tukey's different test was used at 5\% alpha level. 


\section{Conclusion}

Biorational insecticide application had the significant effect on the population density of larvae and intensity of $H$. armigera attack and sweet corn cob yield. Biological insecticide of $B$. bassiana at $5 \mathrm{~g} \mathrm{I}^{-1}$ tended to be more effective than other insecticides, in which population density of $H$. armigera larvae was reached to 0.35 tail per crop, attack intensity of $25.88 \%$, and sweet corn cob yield reached $17.1 \mathrm{t} \mathrm{ha}^{-1}$. Biologic insecticide of $B$. bassiana at $5 \mathrm{~g}^{-1}$ gave the maximum result of cost-benefit ratio of $1: 6.07 . \mathrm{H}$. armigera control should use a biological agent of fungus $B$. bassiana with a dose of $5 \mathrm{~g} \mathrm{I}^{-1}$ because it had a more environmentally friendly nature and tended to be more economical.

\section{Acknowledgments}

The authors would like to thank the reviewers for providing valuable comments and suggestions, and to Research Ministry, Technology and Higher Education of the Republic of Indonesia for providing support for this research.

\section{References}

Adejumo OA, Ojoko EA, Yusuf SA (2014) Factors influencing choice of pesticides used by grain farmers in Southwest Nigeria. J Biol Agric Healthc. 4(28):31-38.

Adeogun SO, Agbongiarhuoyi AE (2009) Assessment of cocoa farmers chemical usage pattern in pest and disease management in Ondo State. J Innov Dev Strategy. 3(2):2734.

Ahmad RZ, Haryuningtyas D, Wardhana A (2008) Lethal time 50 of Beauveria bassiana and Metarhizium anisopliae on Sarcoptes scabiei. National seminar on livestock and veterinary technology. Bogor: veterinary research center.

Antralina M, Santoso J (2015) Influence of biological control agents Helicoverpa armigera nuclear polyhedrosis virus (Ha-npv) on intensity of the attack twig caterpillar (Ectropis bhurmitra Wlk.) and yield of tea plant (Camellia sinensis (L.) O. Kuntze) clone gmb 7. J of Tea and Quinine Res. 18(1):29-36.

Archer TL, Bynum ED (1994) Corn earworm (Lepidoptera: Noctuidae) biology on food corn on the high plains. Environ Entomol. 23: 343-348.

Bayer AG (2015) Decis ${ }^{\circ} E C \quad 25$. https://www.iraq.cropscience.bayer.com/ en/Products/ Insecticides/ Decis-EC-25.aspx. (Accesed 2-8-2015).

Cheung PYK, Grula EA (1982) In vivo events associated with entomophatologhy of Beauveria bassiana for the corn earworm (Heliothis zea). Invert. 39(3):303-313.

Cocco P, Satta G, Dubois S, Pilleri M, Zucca M, Mannetje AM, Becker N, Benavente $Y$, Sanjose SD, Foretova L, Staines A, Maynadie M, Nieters A, Brennan P, Miligi L, Ennas MG, Boffetta P (2013) Lymphoma risk and occupational exposure to pesticides: results of the Epilymph study. Occup Environ Med. 70:91-98.

Elimam AM, Elmalik KH, Ali FS (2009) Larvicidal, adult emergence inhibition and oviposition deterrent effects of foliage extract from Ricinus communis L. against Anopheles arabiensis and Cilex quinquefasciatus in Sudan. Trop Bio. 26: 130-139.
Fitt GP (1989) The ecology of Heliothis species in relation to agro-ecosystems. Annu Rev Entomol. 34: 17-52.

Gill HK, Garg H (2014) Pesticides: environmental impacts and management strategies. In: Soloneski S (ed) Pesticidestoxic aspects. InTech. pp 188-230.

Grainge M, Ahmed S (1988) Handbook of plant with pest control properties. New York: John Willey and Sons.

Guerrero S, Brambila J, Meagher RL (2014) Efficacies of four pheromone-baited traps in capturing male helicoverpa (Lepidoptera: noctuidae) moths in Northern Florida. Florida Ento. 97(4): 1671-1678.

Herlinda S, Utama MD, Pujiastuti Y, Suwandi (2006) Density and viability of spores of Beauveria bassiana (Bals.) Vuill. Due to sub-cultures and media enriched, and its virulence against larvae of Plutella xylostella (Linn.). J HPT Trop. 6(2):70-78.

Hou B, Wu L (2010) Safety impact and farmer awareness of pesticide residues. F Agric Imm. 21:191-200.

Jauharlina (1998) Potential of Beauveria bassiana Vuill. As entomopathogenic fungi on spodoptera litura. F J Agrista. 3(1):64-71.

Kalshoven LGE (1981) The pest of crops in Indonesia. Revised by Van der Laan. PT. Ictiar Baru van Hoeve Jakarta.

Kardinan A (2002) Vegetable pesticides: potions and applications. 4th Edition. Penebar Swadaya. Jakarta.

Kasryno F, Effendi P, Suyamto, Adnyana MO (2007) Overview of maize economy in Indonesia. Corn: Produc and Dev Tech. 474-497. Bogor: Center for food crops research and development.

Konradsen F (2007) Acute pesticide poisoning: a global public health problem. Dan Med Bull. 54(1):58-59.

Kusnadi, Sanjaya Y (2003) Study the efectivlty of Beauveria bassiana toward the mortality of Hypothenemus hampei. Indo J Entom. 9(2):87-91.

Lertrat K, Pulam T (2007). Breeding for increased sweetness in sweet corn. Int J Plant Breed. 1(1):27-30.

Mesnage R, Clair E, de Vendômois JS, Seralini GE (2010) Two cases of birth defects overlapping Stratton-Parker syndrome after multiple pesticide exposure. Occup Environ Med. 67(5):359.

Munawaroh S, Handayani PA (2010) Extraction of lemon leaf oil (Citrus hystrix D.C.) with Ethanol and N-Hexane Solvent. J Tech Comp. 2(1):73-78.

Ntow WJ, Gijzen HJ, Kelderman P, Drechsel P (2006) Farmer perceptions and pesticide use practices in vegetable production in Ghana. Pest Manag Sci. 62(4):356-365.

Patulak L (1995) Study of the intensity of termite damage on mulberry plant and pathogenesis test of Beauveria bassiana as its controlling agent, [Undrgraduate Thesis]. Ujung Pandang: Faculty of Agriculture and Embassy, Hasanuddin University.

Pimentel D (2005) Environmental and socio economic costs of the applications of pesticides primarily in the United States. Environ Dev Sustain. 7: 229-252.

Riyatno, Santoso (1991) The Beauveria bassiana and its developmental ways to control pest of coffee powder. Jakarta: Directorate of Plantation Crop Protection. Directorate General of Plantation.

Sam KG, Andrade HH, Pradhan L, Pradhan A, Sones SJ, Rao PG, Sudhakar C (2008) Effectiveness of an educational program to promote pesticide safety among pesticide 
handlers of South India. Int Arch Occup Environ Health. 81(6):787-795.

Subandi IG, Ismail, Hermanto (1998) Corn, production technology, and post-harvest. Bogor: Center for Food Crop Research and Development.

Sudarmo (1988) Control of corn pests. Jakarta: Penebar Swadaya.

Sugito J, Palungkun R, Liatyowati E (1991) Sweet corn baby corn. Jakarta: Penebar Swadaya.

Sukandar D, Hermanto S, Nurichawati S (2016) Characterization of active compound of rice weevils (Sitophilus oryzae L.) control from distillates of pandan wangi essential oil. Chemistry of Science and Technology Faculty. Syarif Hidayatullah State Islamic University. Jakarta.

Suntoro (1991) Efficacy test of Beauveria bassiana (Bals.) Vuill. Against Hypothenemus hampei (Ferr.). [Master Science Thesis]. Yogyakarta: Gadjah Mada University.

Tanada Y, Harry KK (1993) Insect pathology. Academic press. Inct. Harcaundt. Brace Jovanavich. Publisher San Diego.

Tanner CM, Kamel F, Ross GW, Hoppin JA, Goldman SM, Korell M, Marras C, Bhudhikanok GS, Meike K, Chade AR, Comyns K, Richards MB, Meng C, Priestly B, Fernandez HH, Langston W (2011) Rotenone, paraquat, and parkinson's disease. Environ Health Perspect. 119:866-872.
Topper CP (1987) Nocturnal behaviour of adults of Heliothis armigera (Hübner) (Lepidoptera: Noctuidae) in the Sudan Gezira and pest control implications. Bull Entomol Res. 77: 541-554.

Wiseman BR, Widstrom NW (1992) Resistance of dent corn inbreds to larvae of the corn earworm (Lepidoptera: Noctuidae). J Econ Entomol. 85: 289-292.

Wraight SP, Jackson MA, de Kock SL (2000) Evaluation of the entomopathogenic fungi Beauveria bassiana and Paecillomyces fumosoroseus for microbial control of the siverleaf whitefly, Bemisia argentifolii. Biol Contr. 17:203221.

Yunus M, Pasaru F, Susanti (2016) The effectiveness of leaf extract of Pandanus amaryllifolius Roxb. on mortality of rice weevils, Sitophilus oryzae L. (Coleoptera: Curculionidae). Presented at The National Seminar of Entomology Association of Indonesia on 25-27 November 2016 in Palu.

Zalucki M, Daglish P, Firempong GS, Twine P (1986) The biology and ecology of Heliothis armigera (Hübner) and $H$. punctigera Wallengren (Lepidoptera: Noctuidae) in Australia: what do we know? Austra J Zool. 34: 779-814.

Znidarcic D (2012). Performance and characterization of five sweet corn cultivars as influenced by soil proporties. J Food Agric Environ. 10(1):495-500. 